\title{
ЗМІНА ПОКАЗНИКІВ РОДЮЧОСТІ ТА ЦЕЛЮЛОЗОЛІТИЧНА АКТИВНІСТЬ ҐРУНТУ ЗА ВИРОЩУВАННЯ ЗЛАКОВИХ ТРАВОСТОЇВ
}

\author{
У. М. КАРБІВСЬКА \\ кандидат сільськогосподарських наук, доцент \\ ORCID ID: 0000-0002-0540-8887 \\ ДВНЗ «Прикарпатський національний університет ім. В.Стефаника» \\ вул. Галицька 201, м. Івано-Франківськ, 76000 \\ E-mail: yljakarbivska@ukr.net
}

\begin{abstract}
Анотація. Висвітлено результати досліджень щодо зміни показників родючості та целюлозної активності грунту за вирощування злакових трав залежно від удобрення. Внесення фосфорно-калійних добрив у дозі $P_{60} K_{90}$ суттєво впливало на накопичення сухої кореневої маси лише за поєднаного внесення їх з азотом. На фоні внесення $N_{75}$ приріст кореневої маси збільшився на 0,63 m/2a, а на фоні $\mathrm{N}_{150}$ на 0,63 m/га за НIP ${ }_{0,5} 0,35 \mathrm{~m} / 2 a$. Найбільше кореневої маси нагромаджувалося за внесення мінеральних добрив у дозах $N 150 P_{60} K_{90^{\prime}}$ а найменше -уваріанті без добрив. Фосфору, у корінні злакового травостою орного шару грунту на різних варіантах удобрення накопичувалось у межах від 11 до 17 кг/га, а калію-в межах 50-76 кг/га.

Під дією щорічного внесення на злаковий травостій N75 окремо або в поєднанні з внесенням Р60К90 целюлозна активність грунту збільшилася на 4-5\%, а за внесення $\mathrm{N}_{150}-6 \%$.
\end{abstract}

Ключові слова: удобрення, коріння, грунт, злакові трави, поживні речовини, сінокісне використання, целюлозолітична активність, показники родючості

\section{Актуальність.}

Для того, щоби зберегти і збільшити родючість грунтів, а також підвищити їхню стійкість до несприятливих антропогенних чинників, слід накопичувати органічну речовину в грунті. Через різке зменшення поголів'я худоби в господарствах України розв'язати цю проблему внесенням гною практично неможливо. Тому потрібно знайти шляхи для відновлення та утримання на оптимальному рівні родючість грунтів завдяки альтернативним способам накопичення органічної речовини в грунті. Одним 3 основних ресурсів і перспективним напрямом у розв'язанні цієї проблеми може бути вирощування багаторічних трав (Балаєв А. Д. та ін., 2011).

Застосування добрив є одним із найефективніших заходів поліпшення сінокосів. Під його впливом відбуваються спрямовані зміни умов зростання лучних рослин, що призводить до домінування цінних видів злакових трав (Тебердиев Д. М., Родионова А. В., 2015). 
Для визначення доз добрив застосовують різні методи, у тому числі балансово-розрахунковий, економіко-математичний, метод хімічної діагностики, який грунтується на даних хімічного аналізу рослин, і метод, який базується на рекомендаціях науково-дослідних установ (Кургак В.Г., 2010). Головним критерієм визначення доз добрив для сіножатей i пасовищ, за використання будь-якого методу $є$ дані дослідів: вони ж взяті за основу під час розроблення рекомендацій внесення добрив. Для орієнтовного визначення доз азоту запропоновано користуватися розрахунковим шляхом, зважаючи на середні можливості трав, ефективно використовувати 2,5 кг $\mathrm{N}$ за добу.

\section{Аналіз останніх досліджень та публікацій.}

Однією з основних проблем сьогодення $є$ відтворення родючості грунтів, зокрема дослідження поживного режиму. Це пов язано з необхідністю систематичного підвищення ефективної родючості грунтів, урожайності сільськогосподарських культур і якості отриманої продукції. Агрохімічним властивостям грунтів належить провідна роль у створенні оптимальних умов росту та розвитку сільськогосподарських культур та стабілізації екологічного стану агроландшафтів.

Під час вирощування сільськогосподарських культур до грунту надходить значна частина рослинних решток, основною скдадовою яких є целюлоза. Уміст іiі у рослинах знаходиться в межах 45 - 80\%. В орному шарі їі кількість складає $5 \%$ і є великим резервом грунтової родючості. Целюлозоруйнвіні мікроорганізми здійснюють розклад рослинних решток, виділяючи при цьому в середовище окислювальні ферменти, які володіють властивістю синтезувати гумусові речовини із продуктів розкладу цих решток (Шикула М.К. та ін., 2002).

Особливості дерново-підзолистого грунту, що характеризується кислою реакцією грунтового розчину, відносною бідністю на поживні елементи й органічну речовину, наявністю інертного підзолистого горизонту, а також промивного режиму, визначають і невисокий рівень його біологічної активності. Проте окультурення грунту змінює властивості та умови існування мікроорганізмів унаслідок збагачення необхідними для мікрофлори мінеральними елементами та органічними сполуками (Повх О.В., Мерленко I.М., 2013).

3 огляду на те, що здебільшого грунтів Передкарпаття має низький уміст поживних речовин, для одержання високих і сталих врожаїв потрібно щороку поповнювати їхні запаси фосфором, калієм та інших елементами, але основним лімітувальним чинником $є$ забезпеченість азотом (Ярмолюк М. Т. та ін., 2010).

Для лучних агрофітоценозів характерною $\epsilon$ добре розвинена коренева система-гарант успішної довголітньої експлуатації як за сінокосіння, так і за випасання. Така дернина високоефективно використовує добрива, протистоїть виродженню, формує велику кількість як надземної, так і підземної маси, запобігає ерозії грунтів на схилах. 3 підвищенням доз азотних добрив протиерозійна стійкість лучних травостоїв збільшується (Кургак В.Г., Лук'янець О.П., 2004; Кургак В. Г., Товстошкур В. М., 2010). На початку кожного вегетаційного періоду коріння злаків росте швидше, ніж бобових, і тому 
злаки краще реагують на внесення добрив ранньою весною. Дія добрив знижується, коли погіршуються умови зволоження (Кургак В. Г., Товстошкур В. М., 2010). Багато дослідників виявили, що основна маса коріння (80-90 \%) перебуває у верхньому шарі (0-10 см) грунту та різко зменшується у його профілі. Найкраще вона розвивається у разі достатнього зволоження грунту, а в посушливих умовах кореневих залишків удвічі менше (Оліфірович В. О. та ін., 2018, Ярмолюк М. Т. та ін., 2013).

Раціональне застосування добрив біологічного та хімічного походження сприяє трансформації поживних речовин у грунті, активізації ростових процесів у рослинах, підвищенню біологічної активності мікрофлори грунту, а головне, - збільшує продуктивність сільськогосподарських культур (Векленко Ю.А., Підпалий І.Ф., 2015).

Мета досліджень - визначити вплив злакового травостою та удобрення на целюлозолітичну активність та показники родючості дерново-підзолистого грунту.

\section{Матеріали і методи дослідження.}

Експериментальні дослідження проводили впродовж 2017-2019 pp. на дослідному полі кафедри агрохімії i грунтознавства дендрологічного парку «Дружба» ДВНЗ «Прикарпатського національного університету імені Василя Стефаника» GPS прив'язка: широта 48056'55', довгота - 24041'35”. Дослідження виконували за методикою Інституту кормів НААН (Бабич А. О., 1994).

Облік урожаю проводили шляхом скошування та зважування зеленої маси 3 облікової площі. Урожайні дані обробляли дисперсійним мето- дом (Доспехов, 1985). Перерахунок на абсолютно суху масу проводили за висушування пробного снопа вагою 0,5 кг зеленої маси за температури $105{ }^{\circ} \mathrm{C}$ до постійної ваги. Нагромадження кореневої маси визначали після відбору грунтових проб стаканом розміром 516,9 $\mathrm{cm}^{3}$ на глибині 0-20 см у чотирикратному повторенні 3 наступним відмиванням на ситах діаметром 0,25 мм і зважуванням у повітряно-сухому стані. Дослідження загальної біологічної активності проводили методом Мішустіна, Вострова й Петрової (за інтенсивністю розкладання целюлозолітичної активності грунту використовували шкалу, запропоновану Д.В.Звягінцевим: $10 \%$ - дуже слабка, 10-30 - слабка, 30-50 - середня, 50-80 - сильна, понад 80 \% - дуже сильна).

Лабораторні дослідження проводили в сертифікованій та акредитованій агрохімічній лабораторії кафедри агрохімії і грунтознавства ДВНЗ «Прикарпатський національний університет ім. В. Стефаника». Зразки грунту відбирали перед закладанням досліду та після трьохрічного вирощування трав. Визначали такі показники: вміст загального гумусу - за Тюріним, pH сол. - потенціометрично на іономірі, лужногідролізований азот - за Корнфілдом, рухомий фосфор та рухомий калій за Кірсановим.

Схема досліду включала наступні чинники: чинник $\mathrm{A}$ - види трав та норми висіву їхнього насіння, кг/ га: костриця лучна, $8+$ стоколос безостий, 12 + тимофіївка лучна, 12; чинник В - удобрення: 1. Контроль (без добрив); 2. $\mathrm{P}_{60} ; 3 . \mathrm{K}_{90} ;$ 4. $\mathrm{P}_{60} \mathrm{~K}_{90}, 5$. $\mathrm{N}_{75}$; 6. $\mathrm{N}_{75} \mathrm{P}_{60} \mathrm{~K}_{90}$; 7. $\mathrm{N}_{150}$; 8. $\mathrm{N}_{150} \mathrm{P}_{60} \mathrm{~K}_{90}$ Площа посівної ділянки - $15 \mathrm{~m}^{2}$, облікової - $10 \mathrm{~m}^{2}$, повторність досліду чотириразова, попередник гречка. 
Фосфорно-калійні добрива вносили щорічно поверхнево рано навесні, а азотні - у три прийоми $\mathrm{N}_{25}$ та $\mathrm{N}_{150}$ навесні по мерзлоталому грунті та після першого і другого укосів. У досліді використовували наступні види добрив: азотні - аміачна селітра (34\%), калійні - калімагнезія (26 \%), фосфорні - простий суперфосфат (18,7 \%).

Безпокривну сівбу суміші злакових трав із тимофіївки лучної, стоколосу безостого та костриці лучної провели влітку 2016 року. Використання травостоїв триукісне. Перший укіс проводили у фазі колосіння злаків, отав - через 30-35 днів після попереднього укосу.

Грунт дослідного поля - дерново-підзолистий поверхнево оглеєний на алювіально-делювіальних відкладах. Реакція грунтового розчину сильнокисла ( $\mathrm{pH}-4,6)$. Вміст гумусу в шарі 0-20 cм-2,1\%. Рухомих форм елементів живлення в орному шарі грунту в середньому містилося: рухомого фосфору (67,3 мг/кг грунту) та калію (96,8 мг/кг грунту).

Погодно-кліматичні умови в роки проведення досліджень дещо відрізнялися від середньобагаторічних показників як за кількістю опадів, так i за значеннями середньодобових температур. Так середньодобова температура повітря протягом вегетаційного періоду перевищувала середньо багаторічне значення $\left(15,3{ }^{\circ} \mathrm{C}\right)$ на 0,8 ${ }^{0} \mathrm{C}$. Водночас кількість опадів понад норму (462 мм) було відзначено лише у 2016 році- на 91,6 мм, що позитивно вплинуло на формування врожаю злакової травосумішки в рік посіву. У 2018 році сума опадів була недостатньою на 93,6 мм менше середньо багаторічного значення, що негативно впливало на відростання трав в отавах.

\section{Результати дослідження та їх обговорення.}

Аналіз результатів наших досліджень, проведених упродовж 2017 - 2019 рр. 3 вивчення доз і співвідношень NPK мінеральних добрив на продуктивність показав, що на сіяному злаковому травостої (тимофіївка лучна, стоколос безостий i костриця лучна) найбільш діючим мінеральним поживним елементом виявився азот (табл. 1).

Визначено, що за внесення азоту в дозі $\mathrm{N}_{75}$ з розподілом під кожний із трьох укосів по 25 кг.д.р. на різних фонах фосфорно-калійних добрив, продуктивність злакового травостою в середньому зросла від 2,53-3,47 т/га до 5,35-6,53 т/га сухої маси, а за внесення $\mathrm{N}_{150(50+50+50)}$ відповідно до 7,46-8,80 т/га. Отже, найвищу продуктивність трав'яного корму одержано за внесення $\mathrm{N}_{150}$.

Вивчення зміни показників родючості дерново-підзолистого грунту показало, що багаторічний злаковий травостій за різних доз і співвідношень N, Р, К нагромаджував сухої кореневої маси в межах від 5,21 до 8,07 т/га (табл. 2).

Поміж поживних елементів, як i на продуктивність надземної біомаси, найбільш діючим на нагромадження кореневої маси був азот. Але дія різних його доз була не однаковою. За внесення $\mathrm{N}_{75}$ окремо або в поєднанні 3 внесенням $\mathrm{P}_{60} \mathrm{~K}_{90}$ накопичення сухої кореневої маси збільшилося від 5,21 - 5,45 до 7,32-7,95 т/га 3 приростом на 1 кг азоту $28-33$ кг сухої маси коріння. За внесення $\mathrm{N}_{150}$ окремо або в поєднанні з внесенням $\mathrm{P}_{60} \mathrm{~K}_{90}$ накопичення сухої кореневої маси збільшилося до 7,39-8,07 т/га сухої маси коріння. За внесення $\mathrm{N}_{150}$ у порівнянні 3 дозою $\mathrm{N}_{75}$ збільшення накопичення 


\section{1. Вплив доз і співвідношень NРК добрив на продуктивність злакового травостою}

\begin{tabular}{|l|c|c|c|c|}
\hline \multirow{2}{*}{ Дози добрив } & \multicolumn{3}{|c|}{ Суха маса за роками, т/га } & \multirow{2}{*}{$\begin{array}{c}\text { Суха маса, т/га, серед- } \\
\text { нє за 2017-2019 pp. }\end{array}$} \\
\cline { 2 - 4 } & 2017 & 2018 & 2019 & 2,53 \\
\hline Без добрив & 2,71 & 2,57 & 2,30 & 2,81 \\
\hline $\mathrm{P}_{60}$ & 2,96 & 2,77 & 2,70 & 2,95 \\
\hline $\mathrm{K}_{90}$ & 3,14 & 2,90 & 2,82 & 3,13 \\
\hline $\mathrm{P}_{30} \mathrm{~K}_{45}$ & 3,35 & 3,09 & 2,94 & 3,47 \\
\hline $\mathrm{P}_{60} \mathrm{~K}_{90}$ & 3,78 & 3,38 & 3,24 & 5,35 \\
\hline $\mathrm{N}_{75}$ & 5,57 & 5,34 & 5,13 & 5,76 \\
\hline $\mathrm{N}_{75} \mathrm{P}_{60}$ & 6,19 & 5,61 & 5,49 & 5,81 \\
\hline $\mathrm{N}_{75} \mathrm{~K}_{90}$ & 6,31 & 5,59 & 5,53 & 6,13 \\
\hline $\mathrm{N}_{75} \mathrm{P}_{30} \mathrm{~K}_{45}$ & 6,48 & 6,03 & 5,89 & 6,53 \\
\hline $\mathrm{N}_{75} \mathrm{P}_{60} \mathrm{~K}_{90}$ & 6,78 & 6,55 & 6,25 & 7,46 \\
\hline $\mathrm{N}_{150}$ & 8,13 & 7,19 & 7,06 & 8,02 \\
\hline $\mathrm{N}_{150} \mathrm{P}_{60}$ & 8,66 & 7,81 & 7,59 & 8,20 \\
\hline $\mathrm{N}_{150} \mathrm{~K}_{90}$ & 8,75 & 8,09 & 7,76 & 8,50 \\
\hline $\mathrm{N}_{150} \mathrm{P}_{30} \mathrm{~K}_{45}$ & 9,08 & 8,34 & 8,07 & 8,80 \\
\hline $\mathrm{N}_{150} \mathrm{P}_{60} \mathrm{~K}_{90}$ & 9,28 & 8,75 & 8,38 & 0,38 \\
\hline $\mathrm{HIP}_{05}, \mathrm{r} /$ га & 0,44 & 0,38 & 0,33 & \\
\hline & & & & \\
\hline
\end{tabular}

сухої кореневої маси було не істотним. Внесення фосфорних і калійних добрив у дозі $\mathrm{P}_{60} \mathrm{~K}_{90}$ суттєво впливало на накопичення сухої кореневої маси лише за поєднаного внесення їх 3 азотом. У цьому разі на фоні внесення $\mathrm{N}_{75}$ приріст кореневої маси збільшився на 0,63 т/га, а фоні $\mathrm{N}_{150}$ - на 0,63 т/га за HIP $_{0,5} 0,35$ т/га. Найбільше кореневої маси нагромаджувалося за внесення мінеральних добрив у дозах $\mathrm{N}_{150} \mathrm{P}_{60} \mathrm{~K}_{90}$, а найменше - у варіанті без добрив.

Співвідношення надземної маси до маси коренів, як коефіцієнт продуктивної дії коренів сіяного злакового травостою із суміші трав залежно від доз і співвідношень N, Р, К у наших дослідженнях коливалось у межах 0,49-1,09.

Поміж поживних елементів на коефіцієнт продуктивної дії коріння найбільше впливав азот. За внесення $\mathrm{N}_{75}$ окремо або в поєднанні з внесенням $\mathrm{P}_{60} \mathrm{~K}_{90}$ коефіцієнт продуктивної дії коріння збільшився від 0,49-0,52 до $0,73-0,82$, а за внесення $\mathrm{N}_{150}$ у поєднанні 3 внесенням $\mathrm{P}_{60} \mathrm{~K}_{90}$-до 1,01 - 1,09 або у 2,1 рази.

Під час аналізу накопичення основних поживних елементів у сухій кореневій масі шару грунту $0-20$ см сіяного злакового травостою із суміші трав залежно від доз та співвідношень N, P, K встановлено, що вміст азоту в ній коливався в межах $1,06-1,40 \%$ (табл. 3). За внесення $\mathrm{N}_{75}$ окремо або в поєднанні з внесенням $\mathrm{P}_{60} \mathrm{~K}_{90}$ концентрація азоту в сухому корінні збільшилася від 1,06 - 1,07 до $1,23-1,24$, а за внесення $\mathrm{N}_{150} \mathrm{y}$ поєднанні з внесенням фосфорно-калійних добрив - до 1,38 - 1,40. 
2. Накопичення кореневої маси злаковим травостоєм залежно від удобрення у шарі грунту 0-20 см (середнс за 2017 - 2019 рр.)

\begin{tabular}{|l|c|c|c|}
\hline \multicolumn{1}{|c|}{ Удобрення } & $\begin{array}{c}\text { Суха надземна } \\
\text { маса, } \mathrm{T} / \text { га }\end{array}$ & $\begin{array}{c}\text { Суха коренева } \\
\text { маса, } \mathrm{T} / \text { га }\end{array}$ & $\begin{array}{c}\text { Співвідношення надземної } \\
\text { маси до маси коренів }\end{array}$ \\
\hline Без добрив & 2,53 & 5,21 & $1: 0,49$ \\
\hline $\mathrm{P}_{60}$ & 2,81 & 5,45 & $1: 0,52$ \\
\hline $\mathrm{K}_{90}$ & 2,95 & 5,58 & $1: 0,53$ \\
\hline $\mathrm{P}_{60} \mathrm{~K}_{90}$ & 3,47 & 5,47 & $1: 0,63$ \\
\hline $\mathrm{N}_{75}$ & 5,35 & 7,32 & $1: 0,82$ \\
\hline $\mathrm{N}_{75} \mathrm{P}_{60} \mathrm{~K}_{90}$ & 6,53 & 7,95 & $1: 1,01$ \\
\hline $\mathrm{N}_{150}$ & 7,46 & 7,39 & $1: 1,09$ \\
\hline $\mathrm{N}_{150} \mathrm{P}_{60} \mathrm{~K}_{90}$ & 8,80 & 8,07 & \\
\hline $\mathrm{HIP}_{0.5}$ & 0,38 & 0,35 & \\
\hline
\end{tabular}

Уміст фосфору в сухому корінні коливався в межах $0,19-0,24 \%$, а калію $-0,92-1,03 \%$. Внесення азотних добрив призводило до несуттєвого зменшення вмісту цих елементів у корінні, тоді як внесення фосфору та калію в дозі $\mathrm{P}_{60} \mathrm{~K}_{90}$, на безазотному фоні призводило до збільшення вмісту цих елементів у сухому корінні, відповідно на 2 і 7 \%.

Аналіз показників накопичення в сухому корінні злакового травостою азоту показав, що його на 1 га шарі грунту 0-20 см нагромаджувалось у межах $55-111$ кг/га. Найбільше на накопичення в кореневій масі азоту впливали азотні добрива. За внесення $\mathrm{N}_{75}$ окремо або в поєднанні з внесенням $\mathrm{P}_{60} \mathrm{~K}_{90}$ нагромадження азоту в корінні збільшилося від 55-58 до $91-98$ кг/га або в 1,7 раза, а за внесення $\mathrm{N}_{150}$ у поєднанні 3 внесенням $\mathrm{P}_{60} \mathrm{~K}_{90}$-до $103-111$ кг/га., що зумовлено як збільшенням нагромадження кореневої маси, так і збільшенням кон-

\section{3. Накопичення основних поживних елементів у кореневій масі} злакового травостою залежно від удобрення у орному шарі грунту (середнс за 2017 - 2019 рр.)

\begin{tabular}{|l|c|c|c|c|c|c|}
\hline \multirow{2}{*}{ Удобрення } & \multicolumn{3}{|c|}{ Вміст у коренях, \% в сухій масі } & \multicolumn{3}{|c|}{ Накопичення у коренях, кг/га } \\
\cline { 2 - 7 } & $\mathrm{N}$ & $\mathrm{P}_{2} \mathrm{O}_{5}$ & $\mathrm{~K}_{2} \mathrm{O}$ & $\mathrm{N}$ & $\mathrm{P}_{2} \mathrm{O}_{5}$ & $\mathrm{~K}_{2} \mathrm{O}$ \\
\hline Без добрив & 1,06 & 0,22 & 0,96 & 55 & 11 & 50 \\
\hline $\mathrm{P}_{60}$ & 1,07 & 0,24 & 0,95 & 58 & 13 & 52 \\
\hline $\mathrm{K}_{90}$ & 1,06 & 0,21 & 1,03 & 59 & 12 & 57 \\
\hline $\mathrm{P}_{60} \mathrm{~K}_{90}$ & 1,06 & 0,23 & 0,98 & 58 & 13 & 54 \\
\hline $\mathrm{N}_{75}$ & 1,24 & 0,21 & 0,94 & 91 & 15 & 69 \\
\hline $\mathrm{N}_{75} \mathrm{P}_{60} \mathrm{~K}_{90}$ & 1,23 & 0,22 & 0,95 & 98 & 17 & 76 \\
\hline $\mathrm{N}_{150}$ & 1,40 & 0,19 & 0,92 & 103 & 14 & 70 \\
\hline $\mathrm{N}_{150} \mathrm{P}_{60} \mathrm{~K}_{90}$ & 1,38 & 0,21 & 0,94 & 111 & 17 & 76 \\
\hline $\mathrm{HIP}_{0.5}$ & 0,04 & 0,01 & 0,02 & & & \\
\hline
\end{tabular}


центрації азоту в корінні. Внесення фосфорних і калійних добрив також збільшувало накопичення в корінні азоту на $3-8$ кг/га.

Фосфору в орному шарі грунту на різних варіантах удобрення накопичувалось у межах від 11 до 17 кг/га, а калію - 50 - 76 кг/га. Найбільше фосфору та калію накопичувалося за внесення $\mathrm{N}_{75} \mathrm{P}_{60} \mathrm{~K}_{90}$ i N $\mathrm{N}_{150} \mathrm{P}_{60} \mathrm{~K}_{90}$ з показниками відповідно 17 і 76 кг/га. Внесення фосфорно-калійних добрив збільшувало накопичення цих елементів у корінні відповідно на $2-3$ та $4-7$ кг/га.

Зміна показників фізико-хімічних i агрохімічних властивостей грунту під злаковим травостоєм залежно від доз та співвідношень N, P, К у орному шарі дерново-підзолистого кислого грунту за період із 2017 до 2019 року наведено в таблиці 4.

На варіантах без внесення азоту спостерігалася тенденція до зменшення вмісту рухомого азоту в грунті на 0,3$0,8 \%$. Тим часом як внесення азоту в дозах $\mathrm{N}_{75}$ та $\mathrm{N}_{150}$ сприяло збільшенню його в грунті на 3,1 - 4,2 \% за НIP 0.5 2,7 \%.

За щорічного внесення $\mathrm{P}_{60}$ окремо або в поєднанні з калійними добривами у варіантах без внесення азоту відбулося збільшення вмісту рухомого фосфору на 4,6-9,5 мг/кг за НIP ${ }_{0,5}-4,2$ мг/ кг. На варіантах із внесенням азоту за внесення $\mathrm{P}_{60}$ спостерігалася лише тенденція до збільшення в грунті фосфору.

За щорічного внесення $\mathrm{K}_{90}$ окремо або з фосфорними добривами у варіантах без внесення азоту відбулося несуттєве збільшення рухомого калію. У варіантах без внесення калію відбулося суттєве зменшення вмісту його в грунті, що зумовлено значними виносами калію з урожаєм.

Аналіз результатів досліджень із визначення целюлозолітичної активності грунту під злаковим травостоєм залежно від добрив у орному шарі дерново-підзолистого грунту протягом 2017 - 2019 рр. показали, що в найбільшій мірі на активність впливало щорічне внесення азоту добрив (табл. 5).

Під дією щорічного внесення на злаковий травостій $\mathrm{N}_{75}$ окремо та в поєднанні з внесенням $\mathrm{P}_{60} \mathrm{~K}_{90}$ целюлозолітична активність грунту збільшилася на $4-5 \%$, а за внесення $\mathrm{N}_{150}-6 \%$. Аналогічна закономірність спостерігалась і за роками досліджень.

\section{4. Зміна показників агрохімічних властивостей грунту під злаковим травостосм залежно від доз добрив у шарі грунту 0-20 см}

\begin{tabular}{|l|c|c|c|c|c|c|}
\hline \multirow{2}{*}{ Удобрення } & \multicolumn{2}{|c|}{$\mathrm{N}$ за Корнфілдом, мг/кг } & $\mathrm{P}_{2} \mathrm{O}_{5}$ за Кірсановим, мг/кг & $\mathrm{K}_{2} \mathrm{O}$ за Кірсановим, мг/кг \\
\cline { 2 - 7 } & $2017 \mathrm{p}$. & $2019 \mathrm{p}$. & $2017 \mathrm{p}$. & $2019 \mathrm{p}$. & $2017 \mathrm{p}$. & $2019 \mathrm{p}$. \\
\hline Без добрив & 53,6 & 53,2 & 67,3 & 67,1 & 97,2 & 95,1 \\
\hline $\mathrm{P}_{60}$ & 53,2 & 52,6 & 68,2 & 77,7 & 97,3 & 95,3 \\
\hline $\mathrm{K}_{90}$ & 54,7 & 53,4 & 67,4 & 66,9 & 94,1 & 98,2 \\
\hline $\mathrm{P}_{60} \mathrm{~K}_{90}$ & 53,5 & 52,3 & 67,2 & 68,8 & 97,0 & 99,1 \\
\hline $\mathrm{N}_{75}$ & 52,7 & 55,9 & 67,3 & 63,0 & 93,6 & 87,5 \\
\hline $\mathrm{N}_{75} \mathrm{P}_{60} \mathrm{~K}_{90}$ & 53,5 & 56,6 & 66,3 & 67,5 & 96,8 & 90,6 \\
\hline $\mathrm{N}_{150}$ & 54,6 & 58,8 & 66,5 & 60,3 & 95,5 & 85,9 \\
\hline $\mathrm{N}_{150} \mathrm{P}_{60} \mathrm{~K}_{90}$ & 53,7 & 57,9 & 67,6 & 68,1 & 96,7 & 92,7 \\
\hline $\mathrm{HIP}_{0.5}$ & \multicolumn{7}{|c|}{2,7} & 4,2 & \multicolumn{4}{|c}{4,8} \\
\hline
\end{tabular}




\section{5. Целюлозолітична активність грунту під злаковим травостосм залежно від доз добрив у шарі грунту 0-20 см, \%}

\begin{tabular}{|l|c|c|c|c|}
\hline \multirow{2}{*}{ Удобрення } & \multicolumn{3}{|c|}{ Роки користування } & \multirow{2}{*}{ Середнє } \\
\cline { 2 - 4 } & 2017 & 2018 & 2019 & 11 \\
\hline Без добрив & 10 & 11 & 11 & 11 \\
\hline $\mathrm{P}_{60}$ & 11 & 11 & 12 & 12 \\
\hline $\mathrm{K}_{90}$ & 11 & 12 & 12 & 12 \\
\hline $\mathrm{P}_{60} \mathrm{~K}_{90}$ & 11 & 12 & 12 & 15 \\
\hline $\mathrm{N}_{75}$ & 14 & 15 & 15 & 15 \\
\hline $\mathrm{N}_{75} \mathrm{P}_{60} \mathrm{~K}_{90}$ & 14 & 15 & 15 & 17 \\
\hline $\mathrm{N}_{150}$ & 16 & 17 & 17 & 18 \\
\hline $\mathrm{N}_{150} \mathrm{P}_{60} \mathrm{~K}_{90}$ & 17 & 18 & 18 & 2 \\
\hline $\mathrm{HIP}_{0.5}$ & 2 & 1 & 2 & \\
\hline
\end{tabular}

\section{Висновки та перспективи.}

Застосування азотних добрив на злаковому травостої в дозах $\mathrm{N}_{75}$ та $\mathrm{N}_{150}$ сприяло збільшенню азоту в грунті на $3,1-4,2 \%$ за $\mathrm{HIP}_{0,5} 2,7 \%$. Без внесення азоту в сухому корінні багаторічних злакових травостоїв міститься $0,89-1,07 \%$ азоту, $0,21-0,24 \%$ фосфору і $0,95-1,03 \%$ калію, а нагромаджується на 1 га цих елементів відповідно $-57-59$ кг, $12-18$ і $50-70$ кг.

У разі збільшення дози азоту на злаковому травостої до $\mathrm{N}_{150}$ у порівняні 3 $\mathrm{N}_{75}$ збільшується коефіцієнт продуктивної дії коріння - в 1,4 рази, а вміст азоту в сухому корінні - на $0,15-0,16$ $\%$. Уміст фосфору та калію в сухому корінні збільшується в порівнянні 3 варіантом без внесення добрив відповідно на $0,02 \%$ за внесення $\mathrm{P}_{60}$, та на $0,07 \%$ - за внесення $\mathrm{K}_{90}$.

Під дією щорічного внесення на злаковий травостій $\mathrm{N}_{75}$ окремо та в поєднанні з внесенням $\mathrm{P}_{60} \mathrm{~K}_{90}$ целюлозолітична активність грунту збільшилася на $4-5 \%$, а за внесення $\mathrm{N}_{150}-6 \%$.

Вважаємо за необхідне застосовувати мінеральні добрива під злакові травостої, які підвищують целюлозну активність грунту та нагромадження органічної речовини в ньому.

\section{References}

1. Ahroekolohichne obgruntuvannia adaptyvnykh resursooshchadnykh tekhnolohii stvorennia ta vykorystannia bahatorichnykh kormovykh ahrofitotsenoziv / Yu. A. Veklenko ta in. Visnyk ahrarnoi nauky. 2013. Spets. vyp. S.78-83.

2. Babych A.O. Metodyka provedennia doslidiv z kormo vyrobnytstva ta hodivli tvaryn. Kyiv, $1994.80 \mathrm{~s}$.

3. Balaiev A.D., Kovalchuk O.P., Doroshkevych N.F.(2011). Zmina vmistu ta zapasiv humusu $v$ siromu lisovomu grunti za zastosuvannia riznykh syderalnykh kultur yak zelenoho dobryva. Kormy i kormovyrobnytstvo. Vyp.70. S.106-110.

4. Veklenko Yu.A., Korniichuk O.V., Kovtun K.P. Ta In.. (2013). Suchasni systemy vedennia lukopasovyshchnoho hospodarstva v Ukraini. / [Modern Pasture Management Systems in Ukraine]. Kiev: Ahrarna nauka, $32 \mathrm{~s}$.

5. Dospekhov B.A. Metodyka polevoho орыta (s osnovamy statystycheskoi obrabotky 
rezultatov yssledovanyi). Yzd.5-e. dop. y pererab. Moskva, 1985. $351 \mathrm{~s}$.

6. Ekobiolohichni y ahrotekhnichni osnovy stvorennia ta vykorystannia travianystykh fitotsenoziv / M.T.larmoliuk ta in. Lviv: PAIS, 2010. 232 s.

7. Kurhak V. H., Lukianets O.P. (2004). Vplyv typu travostoiu, system udobrennia ta vykorystannia na produktyvnist sukhodilnykh luchnykh uhid pivnichnoho Lisostepu Ukrainy. / [Influence of grass type, fertilizer systems and utilization on the productivity of land meadows of the northern Forest-Steppe of Ukraine]. Zbirnyk naukovykh prats Vinnytskoho derzhavnoho ahrarnoho universytetu. Vyp. 17. S.9-15.

8. Kurhak V. H., Tovstoshkur V. M. (2010). Vplyv vydovoho skladu ta udobrennia bahatorichnykh travostoiv na pokaznyky rodiuchosti gruntiv. Zbirnyk naukovykh prats NNTs «Instytut zemlerobstva UAAN». Vyp. 3/4. S. 15-25.

9. Kurhak V. H. (2010). Luchni ahrofitotsenozy./[Meadow agrophytocenoses]. Kiev. DIA, $370 p$
10. Olifirovych V.O., Osadchuk V.D., Chynchyk O.S., Kravchenko V.S. (2018). Nahromadzhennia korenevoi masy bobovo-zlakovoho travostoiu zalezhno vid skladu travosumishky ta udobrennia. [The accumulation of root mass of legumes and grasses depending on the composition of the grass mix and fertilizer]. Visnyk ahrarnoi nauky. Vyp.11.S.201-208.

11. Povkh O.V., Merlenko I.M. Stan mikrobiotsenozu dernovo-pidzolystoho supishchanoho hruntu pid vplyvom orhanichnykh dobryv ta mikrobiolohichnykh preparativ. Visnyk Sumskoho natsionalnoho ahrarnoho universytetu. 2013. Vyp. 3. S.61-64.

12. Teberdyev D. M., Rodyonova A. V. (2015). Efektyvnost udobrenyi na dolholetnem senokose. Kormoproyzvodstvo. № 10. S. 3-7.

13. Yarmoliuk M.T. Sedilo H.M. Konyk H.S. ta in. (2013). Ahroekobiolohichni osnovy stvorennia ta vykorystannia luchnykh fitotsenoziv. / [Agroecobiological bases of creation and use of meadow phytocoenoses: monogr]. Lviv: SPOLOM, 304 p.

\section{Karbivska U. M. (2020). CHANGE OF INDEXES OF FERTILITY AND CELLULOSE ACTIVITY OF SOIL FOR GROWING OF CEREAL TPABOCTOEB DEPENDING ON A FERTILIZER . PLANT AND SOIL SCIENCE, 11(1): 33-41.} https://doi.org/10.31548/agr2020.01.033

Abstract. The results of researches are reflected in relation to the change of indexes of fertility and cellulose activity of soil for till of cereal herbares depending on a fertilizer. Bringing of phosphoric - of potassium fertilizers in the dose of $P_{60} K_{90}$ substantially influenced on the accumulation of dry root mass only at the united bringing them with nitrogen. On a background bringing of $N_{75}$ the increase of root mass increased on 0,63 t/ha, and on a background $N_{150}-$ on $0,63 \mathrm{t} / \mathrm{ha}$.

Change of indexes of fertility and cellulose activity of soil for growing of cereal mравостоев depending on Most root mass accumulated for bringing of mineral fertilizers in the doses of $N_{150} P_{60} K_{90^{\prime}}$ and least-in a variant without fertilizers. To phosphorus, in the roots of cereal травостоя in a top-soil on the different variants of fertilizer from 11 to $17 \mathrm{~kg} / \mathrm{ha}$ accumulated in limits and, and to potassium - within the limits of $50-76 \mathrm{~kg} / \mathrm{ha}$.

Under operating of the annual bringing on cereal mравостой of $N 75$ separately or in combination with bringing of P60K90 cellulose activity of soil increased on 4 - 5 for bringing of $\mathrm{N} 150-6 \%$.

Keywords: fertilizer, root, soil, cereal herbares, nutritives, haying use, cellulose activity, indexes of fertility 